\title{
Migration Status, Work Conditions and Health Utilization of Female Sex Workers in Three South African Cities
}

\author{
Marlise Richter $\cdot$ Matthew F. Chersich $\cdot$ \\ Jo Vearey $\cdot$ Benn Sartorius $\cdot$ Marleen Temmerman • \\ Stanley Luchters
}

Published online: 13 December 2012

(C) The Author(s) 2012. This article is published with open access at Springerlink.com

\begin{abstract}
Intersections between migration and sex work are underexplored in southern Africa, a region with high internal and cross-border population mobility, and HIV prevalence. Sex work often constitutes an important livelihood activity for migrant women. In 2010, sex workers trained as interviewers conducted cross-sectional surveys with 1,653 female sex workers in Johannesburg (Hillbrow and Sandton), Rustenburg and Cape Town. Most (85.3\%) sex workers were migrants (1396/1636): $39.0 \%$ (638/ $1636)$ internal and $46.3 \%$ (758/1636) cross-border. Crossborder migrants had higher education levels, predominately worked part-time, mainly at indoor venues, and earned more per client than other groups. They, however, had $41 \%$ lower health service contact (adjusted odds ratio $=0.59 ; 95 \%$ confidence interval $=0.40-0.86)$ and less frequent condom use than non-migrants. Police interaction was similar. Cross-border migrants appear more tenacious in certain aspects of sex work, but require
\end{abstract}

M. Richter $(\varangle) \cdot$ M. F. Chersich · M. Temmerman .

S. Luchters

Department of Obstetrics and Gynaecology, International Centre

for Reproductive Health, Ghent University, Ghent, Belgium

e-mail: Marlise.richter@gmail.com

M. F. Chersich

e-mail: mfchersich@gmail.com

M. Temmerman

e-mail: Marleen.Temmerman@ugent.be

S. Luchters

e-mail: sluchters@burnet.edu.au

M. Richter · J. Vearey

African Centre for Migration \& Society, University

of the Witwatersrand, Johannesburg, South Africa

e-mail: jovearey@gmail.com increased health service contact. Migrant-sensitive, sex work-specific health care and health education are needed.

Keywords Sex work - Condoms · Health care utilization · Migration status $\cdot$ South Africa

\section{Background}

Southern Africa is home to the largest population of people with HIV globally [56]. A meta-analysis showed that sex workers in sub-Saharan Africa were 12.4 times more likely than the general population to acquire HIV, with $95 \%$ confidence interval (CI) estimates ranging from 8.9 to 17.2 [6]. Further, female sex workers (FSWs) who are migrants in lower-income countries have higher HIV risks than nonmigrants [37] Despite this, appropriate legal, policy and programmatic responses to HIV, migration and sex work

M. F. Chersich

Faculty of Health Sciences, Centre for Health Policy,

School of Public Health, University of the Witwatersrand,

Johannesburg, South Africa

B. Sartorius · S. Luchters

School of Public Health, Faculty of Health Sciences,

University of the Witwatersrand, Johannesburg, South Africa

e-mail: Benn.Sartorius@wits.ac.za

S. Luchters

Centre for International Health, Burnet Institute,

Melbourne, Australia

S. Luchters

School of Public Health and Preventive Medicine,

Monash University, Melbourne, Australia 
are lacking in Africa $[42,44,48,57,64]$ and sex work remains mostly criminalised across the continent $[50,64]$.

Internationally, studies have highlighted clear linkages between migration and sex work $[2,10,11,58]$. In southern Africa, whilst several studies have documented associations between migration and informal livelihood activities [1, 27, $36,38,64]$, little research has focused specifically on the overlap between sex work and migration.

This study therefore assessed selected structural determinants of vulnerability of migrant FSWs (economic environment and working conditions) and whether access to health services varies between non-migrants, internal migrants and cross-border migrants. The study, in four sites in South Africa, evaluates outcomes based on a conceptual framework (Fig. 1). This framework draws on previous evidence showing that health status and HIV risk among sex workers is contingent on sole economic dependence on sex work, safety of the work environment and degree of responsiveness of health services [8, 13, 40, 46, 67]. Clients often demand unprotected sex [12, 35, 39], and the ability of sex workers to negotiate safer sex depends on their degree of economic vulnerability, and the prevailing power relations between sex workers and clients, and between sex workers and law enforcement agencies [7, 16, 67]. In South Africa, cross-border migrants face high levels of police harassment [25] and difficulties in accessing health services because of language problems or xenophobic health care workers [23]. We hypothesise that these experiences extend to migrant sex workers, and influence their economic dependence on sex work, safety of work conditions and contact with health services.

\section{Methods}

\section{Study Setting}

Cross-sectional surveys with self-identified FSWs were conducted around the time of the 2010 Soccer World Cup, during which few changes in FSW demographics were documented [43]. Two contrasting areas of Johannesburg, the largest city in South Africa, were selected: Hillbrow and Sandton. The inner-city area of Hillbrow was chosen as it has a well-known, long-standing sex trade and is a popular destination for newly-arrived migrants [32, 33, 42, $51,62,69]$. Sandton, by contrast, is a wealthy suburb and business district [5] with a visible outdoor sex industry. The Rustenburg site, in a predominantly rural province, comprised informal settlements within a platinum mine area about $15 \mathrm{~km}$ outside the city. Its sex work industry mainly serves the local mining community [4]. The coastal city of Cape Town is a popular international tourist destination [45], with a relatively well documented sex work industry [17-20, 35]. Commercial sex work, for purposes of this study, was defined as the exchange of sexual
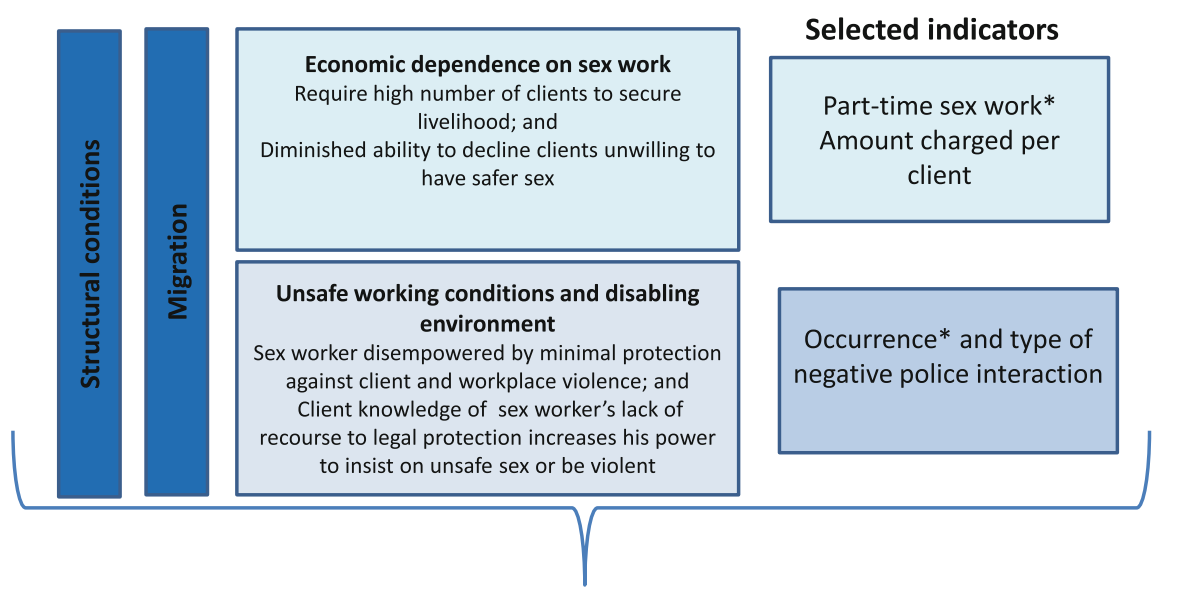

Unsafe working conditions and disabling environment

Sex worker disempowered by minimal protection against client and workplace violence; and

Client knowledge of sex worker's lack of recourse to legal protection increases his power to insist on unsafe sex or be violent

Vulnerability to poor health and wellbeing

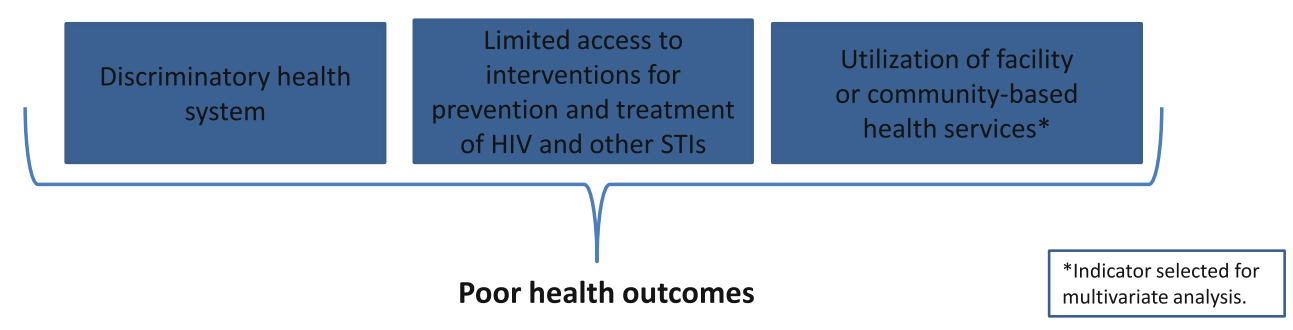

Fig. 1 Factors influencing health outcomes of non-migrant, internal migrant and cross-border migrant sex workers 
services for financial reward in women above 18 years. Detailed methods are described elsewhere [43].

\section{Data Collection}

Between May and September 2010, university-based researchers collaborated with two non-governmental organisations-the Sex Worker Education and Advocacy Taskforce (SWEAT) and Sisonke Sex Worker Movement [68]. Sex worker peer educators and other sex workers attended a training workshop addressing research ethics, participant selection and interviewing. Ten research assistants were selected per site, with those in Hillbrow also collecting data in Sandton.

Research assistants administered a 43-item semi-structured questionnaire to approximately 60 sex workers each. To minimise selection bias, they approached every third woman known to them as a sex worker and invited her to participate. Questionnaires were adapted from tools used in previous studies with sex workers in Mombasa, Kenya [29] and research on migration and access to health care in Johannesburg [59]. Study tools were translated from English into Afrikaans, isiXhosa, isiZulu and Setswana.

\section{Ethical Considerations}

Participants provided written informed consent and were offered a cell-phone airtime or grocery voucher of 20 South African Rand ( $\sim$ US\$3) for time taken in interview. Women were referred to local counselling, health and legal assistance organizations, when required. Participants were given female condoms and information about a newly established toll-free sex worker helpline. As sex work is criminalized in South Africa [9], no identifying information was collected. Study databases were password-protected, with access restricted to the research team. The University of the Witwatersrand Human Research Ethics Committee approved the protocol (Protocol no. H100304).

\section{Study Measures \& Data Analysis}

Data were entered in duplicate in Microsoft Access by separate data clerks. Participants were asked to indicate if they had been interviewed previously and data from repeat interviews (356 of 1,696 women) was excluded from analysis. We compared socio-demographic characteristics and study outcomes between three study groups: (1) non-migrant females working in the province of their birth, (2) internal migrants, born in different province from where they work, and (3) cross-border migrants, women born in another country.

Based on previous evidence, three categories of risk factors were defined, each measured as a binary outcome: economic dependence on sex work [8] (earns income outside sex work, i.e. part-time sex workers), unsafe work environment [7] (had negative interaction with law enforcement in past year) and health services contact [8] (contact in past month with facility- or community-based health services such as peer education or outreach). Part-time sex work was defined as having any other income aside from sex work [22]. Free text descriptions about contact with the police in the preceding year were coded as a "negative interaction" if it concerned police violence, arrest, harassment, theft, bribery or fines. Conversely, "positive interaction" denoted police assistance with, for example, laying a complaint or warning a participant about potential danger. Weekly income was calculated from the mean amount charged with last two clients, and multiplying that by the number of clients in past week (7.5 South African Rand = 1 US Dollar).

Chi square tests were used to detect differences between categorical variables. For continuous variables, The Kruskal-Wallis test compared those with a non-normal distribution, and ANOVA test those with a normal distribution. Bivariate analysis was conducted to assess possible confounding by site. Associations between migration group and the three study outcomes were assessed in multivariable logistic regression analysis, controlling for site of enrolment, socio-demographic and sex work confounders. Variables associated with the primary outcome in bivariate analysis or in similar studies were included in the initial model and retained if their removal from the model markedly altered the model fit.

\section{Results}

\section{Population Description}

Of 1,653 participants, 17 did not state birthplace and were excluded from analysis, while $240(14.7 \%)$ were nonmigrants, $638(39.0 \%)$ internal migrants and $758(46.3 \%)$ cross-border migrants. Participants were a mean 29.7 years, similar in the three study groups. Across groups, more than $40 \%$ of participants had spent five or more years in sex work. There was a difference in number of dependents (child and adult) between the groups: a median two for non-migrants, three for internal migrants and four for cross-border migrants $(P<0.001)$. More cross-border migrants $(39.6 \%)$ had a regular partner than internal migrants $(30.6 \% ; P<0.001)$ or non-migrants $(27.9 \% ; P=0.01)$. However, cross-border migrants who had a regular partner were less likely to live with him/her $(34.1 \%)$ than their internal migrant $(43.2 \%$; $P<0.001)$ or non-migrant $(54.5 \% ; P=0.01)$ counterparts.

Over one-third (276/733) of cross-border migrants had completed secondary school or some tertiary training, 2.2 fold more than the other two groups $(95 \%$ CI odds ratio $[\mathrm{OR}]=1.5-3.1)$. These levels were similar between internal 
Fig. 2 Place of origin of internal migrants according to research site

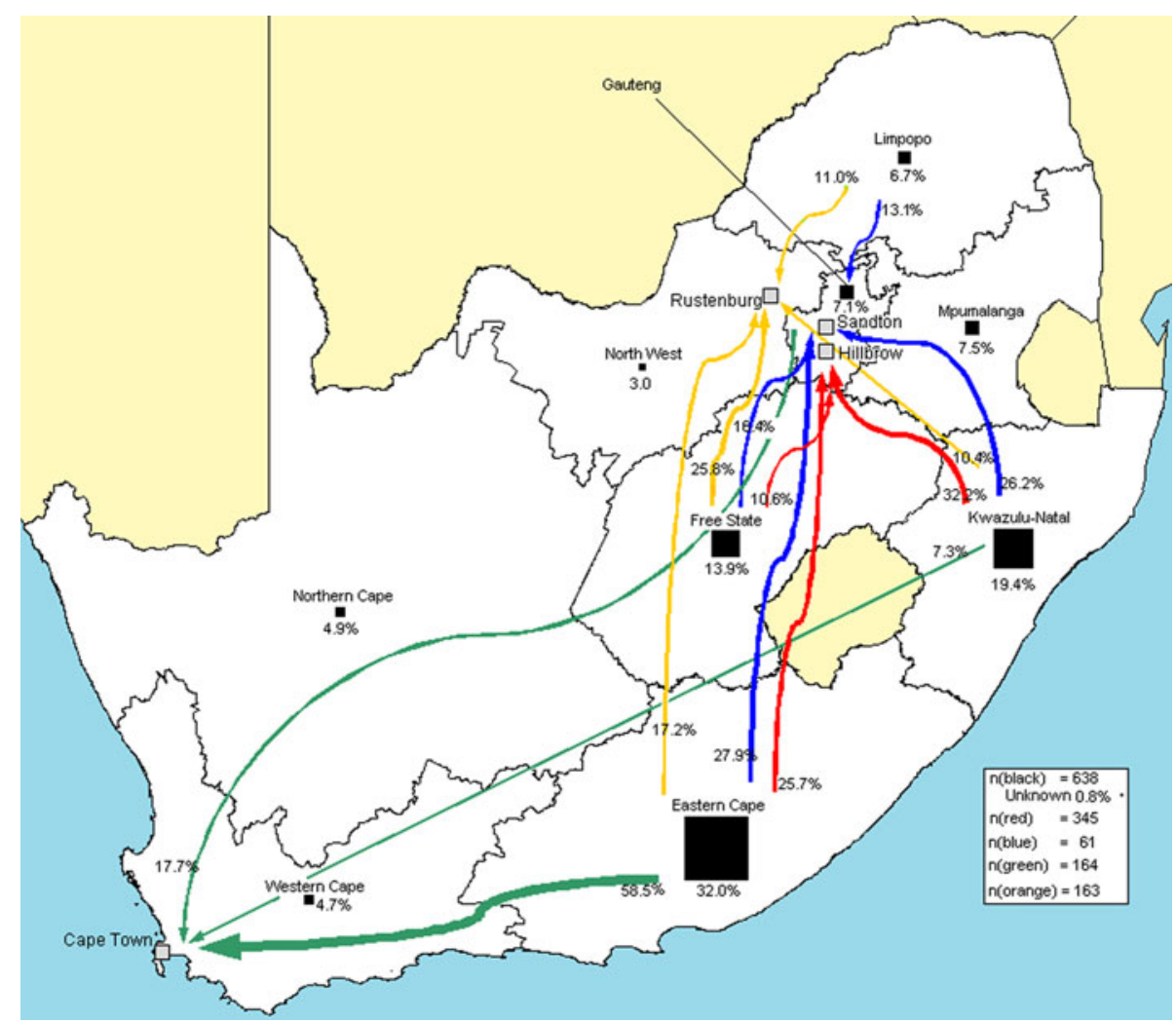

migrants and non-migrants $(\mathrm{OR}=1.1 ; 95 \% \mathrm{Cl}=0.8-1.6)$. Cross-border migrants took up sex work at an older age (mean $=24.9$ years, standard deviation $[\mathrm{SD}]=5.3$ ) than non-migrants $($ mean $=23.0$ years; $\mathrm{SD}=5.4 ; P<0.001$ ). Approximately $60 \%$ of all migrants - similar among internal (332/551) and cross-border migrants (357/600)—started sex work within two years of arrival in the city. Notably, a quarter of cross-border participants $(152 / 626)$ were sex workers before leaving their place of birth compared to only about $10 \%$ of internal migrants $(58 / 539, P<0.001$; data not shown).

Eastern Cape province was the biggest contributor of internal migrants (204) to the four sites, exceeding the 124 internal migrants from KwaZulu-Natal and 89 from the Free State (Fig. 2). This echoes recent findings that the Eastern Cape is one of South Africa's poorest provinces, with high rates of outmigration [41, 52]. Hillbrow and Sandton had the highest proportion of cross-border migrants $(51.9 \%, 308 / 594$ in Hillbrow and $66.1 \%$, 193/292 in Sandton). For all sites, most cross-border migrants hailed from South Africa's neighbouring countries-notably Zimbabwe (Fig. 3). Participants from Zimbabwe had a greater number of total dependants $($ median $=5)$, than South Africans (median $=3$ ) or those born in other countries (median $=4 ; P \leq 0.001$ ). Half of non-migrants (117/233) and a third of internal migrants solicited outdoors (195/600; $P<0.001)$, compared to only
$22.8 \%$ of cross-border migrants $(P<0.001)$. The latter group predominately worked indoors $(52.0 \%, 372 / 715)$, especially in Hillbrow where two-thirds worked indoors (186/282) Table 1.

Economic Dependence on Sex Work

More than a third (256/723) of cross-border migrants worked as part-time sex workers, in contrast to a quarter of internal migrants $(150 / 606 ; P<0.001$; Table 2$)$, and a fifth of non-migrants $(40 / 213 ; P<0.001)$. In bivariate analysis assessing this outcome in each site, patterns of part-time work across the study groups were similar to overall findings, except in Rustenburg. Here, for each migrant group, about $20 \%$ worked part-time. After adjusting for confounding factors including site, cross-border migrants were 2.3 times more likely to work as part-time sex workers than non-migrants $(95 \%$ CI adjusted-OR $[\mathrm{AOR}]=1.5-3.7$; Table 3 ). Similarly, women with some tertiary training compared to those who had not completed primary school had a twofold odds of being a part-time sex worker $(95 \%$ CI AOR $=1.1-3.6)$. Women who had a permanent partner were 2.8 times more likely to be a parttime sex worker than those who were single $(95 \% \mathrm{CI}$ $\mathrm{AOR}=2.1-3.6$ ). Consistent with this, in a univariate analysis, women who actually lived with their partner were 3.1 fold $(95 \%$ CI OR $=2.3-4.2)$ more likely to be part- 
Fig. 3 Place of origin of crossborder migrants according to research site

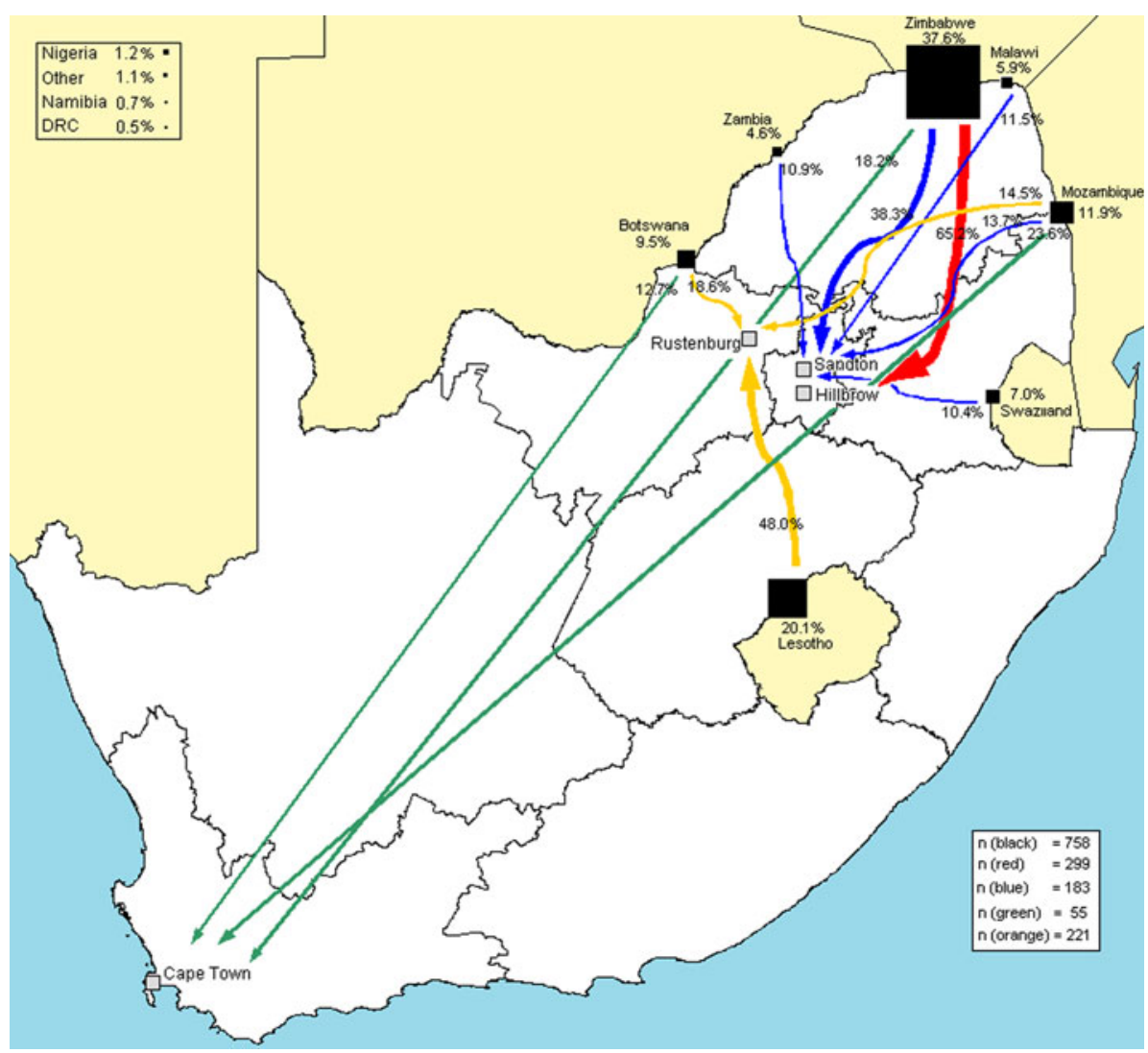

time sex workers than those not living with their partners, or who were single (data not shown).

Cross-border migrants charged a median $\$ 7$ more with their last client $(\$ 20)$, than internal migrants $(P<0.001)$ or non-migrants $(P=0.01)$. Median number of clients in the past week was 14 for cross-border and 15 for internal migrants, double the median number of clients of nonmigrants $(P<0.001)$. Zimbabwean women had a considerably higher median number of clients per week $(n=18)$, than their counterparts from South African $(\mathrm{n}=11)$ or elsewhere (n $=12 ; P \leq 0.001)$. Among full-time sex workers only, non-migrants received the lowest weekly income at $\$ 126.70$ $(\mathrm{IQR}=65.3-280)$ compared to internal migrants' $\$ 200$ $(\mathrm{IQR}=88-466.7)$ and the $\$ 233.33(\mathrm{IQR}=116.7-554.6$; $P<0.001$ ) of cross-border migrants (data not shown).

\section{Unsafe Work Conditions}

More than $40 \%$ of participants had some contact with police in the past year, with almost a third having a negative experience. Occurrences were similar across study groups, including in multivariate analysis, though the nature of police interaction differed. Cross-border migrants had more experience of police bribes $(5.2 \%)$ or issues relating to immigration (5.5\%) than the internal migrants (3.2 and $0.2 \%$, respectively) and non-migrants (2.5 and $0.5 \%$, respectively). In Hillbrow, $9.8 \%$ of cross-border sex workers had interacted with police on immigration, as opposed to $4.9 \%$ in Sandton, $0.6 \%$ in Rustenburg and $0 \%$ in Cape Town. Sex workers in outdoor settings were 1.6 fold (AOR, $95 \% \mathrm{CI}=1.2-2.4$ ) more likely to have adverse interactions, than women in indoor settings. Also, negative police interaction was more than twice as likely among those in the industry for $1-5$ years than those who had just started sex work (AOR $=2.2 ; 95 \% \mathrm{CI}=1.4$ 3.4), and such encounters were almost three times as likely among those in the industry for more than 5 years $(95 \%$ $\mathrm{CI}=1.8-4.5)$. FSWs in Rustenburg were much less likely to experience negative police interaction than those in Cape Town (AOR $=0.06 ; 95 \% \mathrm{CI}=0.03-0.13$ ), though levels in Sandton were 1.82-fold higher than the latter city ( $95 \%$ CI AOR $=1.15-2.88$ ).

\section{Health Care Utilization}

Close to $60 \%$ of participants in each group interacted with health service in the last month. However, in a sub-analysis of utilization in Cape Town, non-migrants had more contact than cross-border sex workers (72.8 vs. $50.0 \%$; $P=0.002$ ), and $81.8 \%$ of non-migrants had contact in the past month in Hillbrow versus $75.0 \%$ of cross-border migrants $(P=0.38$, data not shown). In multivariate analysis controlling for site and other confounders, crossborder migrants were less likely to access health care 
Table 1 Description of socio-demographics, sex work and migration characteristics of female sex workers in four sites in South Africa $(\mathrm{N}=1636)$

\begin{tabular}{|c|c|c|c|c|}
\hline Variables & Non-migrant $n=240$ & $\begin{array}{l}\text { Internal migrant } \\
\mathrm{n}=638\end{array}$ & $\begin{array}{l}\text { Cross-border migrant; } \\
\mathrm{n}=758\end{array}$ & $P$ value $^{\mathrm{b}}$ \\
\hline Age, mean years (SD) & $29.6(6.8), \mathrm{n}=240$ & $29.9(6.5), \mathrm{n}=633$ & $29.7(6.4), \mathrm{n}=757$ & $<0.78^{\mathrm{c}}$ \\
\hline \multicolumn{5}{|l|}{ Site, n/N (\%) } \\
\hline Hillbrow, Johannesburg & $35 / 240(14.6 \%)$ & $246 / 638(38.6 \%)$ & $299 / 758(39.5 \%)$ & \multirow{4}{*}{$<0.001$} \\
\hline Sandton, Johannesburg & $20 / 240(8.3 \%)$ & $64 / 638(10.0 \%)$ & $183 / 758(24.1 \%)$ & \\
\hline Cape Town & $134 / 240(55.8 \%)$ & $164 / 638(25.7 \%)$ & $55 / 758(7.3 \%)$ & \\
\hline Rustenburg & $51 / 240(21.3 \%)$ & $164 / 638(25.7 \%)$ & $221 / 758(29.2 \%)$ & \\
\hline \multicolumn{5}{|l|}{ Education, n/N (\%) } \\
\hline Primary incomplete & $45 / 228(19.7 \%)$ & $117 / 614(19.1 \%)$ & $134 / 733(18.3 \%)$ & \multirow[t]{4}{*}{$<0.001$} \\
\hline Completed primary & $133 / 228(58.3 \%)$ & $350 / 614(57.0 \%)$ & $323 / 733(44.1 \%)$ & \\
\hline Completed secondary school & $42 / 228(18.4 \%)$ & $106 / 614(17.3 \%)$ & $223 / 733(30.4 \%)$ & \\
\hline Some tertiary training & $8 / 228(3.5 \%)$ & $41 / 614(6.7 \%)$ & $53 / 733(7.2 \%)$ & \\
\hline Median number of dependants,(IQR) & $2(1-4)$ & $3(2-6)$ & $4(2-6)$ & $<0.001^{\mathrm{d}}$ \\
\hline \multicolumn{5}{|l|}{ Relationship status, n/N (\%) } \\
\hline Single & 170/237 (71.7\%) & $435 / 626(69.5 \%)$ & $451 / 747(60.4 \%)$ & \multirow[t]{3}{*}{$<0.001$} \\
\hline Regular partner & $66 / 237(27.9 \%)$ & $190 / 626(30.6 \%)$ & $296 / 747(39.6 \%)$ & \\
\hline Lives with regular partner & $36 / 66(54.5 \%)$ & $82 / 190(43.2 \%)$ & $101 / 296(34.1 \%)$ & \\
\hline Age at sex work debut, mean years (SD); $\mathrm{n}$ & $23.0(5.4) ; \mathrm{n}=212$ & $24.0(5.1) ; \mathrm{n}=585$ & $24.9(5.3) ; \mathrm{n}=684$ & $<0.001^{\mathrm{c}}$ \\
\hline \multicolumn{5}{|l|}{ Duration in sex work, $\mathrm{n} / \mathrm{N}(\%)$} \\
\hline$<1$ year & $33 / 217(15.2 \%)$ & 78/583 (13.4\%) & 134/692 (19.4\%) & \multirow[t]{3}{*}{0.03} \\
\hline $1-5$ years & $81 / 217(37.3 \%)$ & $232 / 583(39.8 \%)$ & $278 / 692(40.2 \%)$ & \\
\hline$>5$ years & $103 / 217(47.5 \%)$ & $273 / 583(46.8 \%)$ & $280 / 692(40.5 \%)$ & \\
\hline \multicolumn{5}{|l|}{ Main place solicit clients ${ }^{\mathrm{a}}, \mathrm{n} / \mathrm{N}(\%)$} \\
\hline Indoors & $64 / 233(27.5 \%)$ & $259 / 600(43.2 \%)$ & $372 / 715(52.0 \%)$ & \multirow[t]{3}{*}{$<0.001$} \\
\hline Outdoors & $117 / 233(50.2 \%)$ & $195 / 600(32.5 \%)$ & $163 / 715(22.8 \%)$ & \\
\hline Combination of venues & $52 / 233(22.3 \%)$ & $146 / 600(24.3 \%)$ & $180 / 715(25.2 \%)$ & \\
\hline \multicolumn{5}{|l|}{ Sex work initiation, $\mathrm{n} / \mathrm{N}(\%)$} \\
\hline Before arrival in city & - & 105/551 (19.1\%) & $177 / 600(29.5 \%)$ & \multirow[t]{3}{*}{$<0.001$} \\
\hline Within 2 years of arrival in city & & $332 / 551(60.3 \%)$ & $357 / 600(59.5 \%)$ & \\
\hline 2 or more years of arrival in city & & $114 / 551(20.7 \%)$ & $66 / 600(11.0 \%)$ & \\
\hline Median months since leaving birthplace, (IQR) & - & $79.2(28.2-131.2)$ & $47.2(18.1-111.0)$ & $<0.001^{\mathrm{d}}$ \\
\hline $\begin{array}{l}\text { Median months since arrival in current workplace, } \\
\text { (IQR) }\end{array}$ & - & $67.7(24.2-123.8)$ & $41.0(16.2-90.0)$ & $<0.001^{\mathrm{d}}$ \\
\hline
\end{tabular}

$S D$ standard deviation, $I Q R$ inter-quartile range

${ }^{a}$ Indoors includes working from brothels, bars or massage parlours; outdoors includes street-based sex workers; and women reporting both these were classified as combination venues

${ }^{\mathrm{b}}$ Chi square test unless indicated

c ANOVA test

${ }^{\mathrm{d}}$ Kruskal-Wallis test; All tests compare distribution across all three study groups apart from time since leaving birthplace and arrival in workplace

$(\mathrm{AOR}=0.6 ; 95 \% \mathrm{CI}=0.4-0.9 ;$ Table 3$)$ than nonmigrants. Health contact was considerably higher in Hillbrow than other sites. Non-migrants were more likely to use a condom during penetrative sex with last client (217/ $230 ; 94.6 \%)$ than internal $(558 / 626 ; 89.1 \% ; P=0.02$, data not shown) or cross-border migrants (677/747; $90.6 \% ; P=0.08)$.

\section{Discussion}

In this survey, nearly half of FSWs were cross-border migrants. Two-thirds of the cross-border sex workers in Hillbrow migrated from neighbouring Zimbabwe, mirroring the escalation in Zimbabwean migration to South Africa in search of improved livelihood opportunities 
Table 2 Association between migrant type and economic dependence on sex work, work conditions and health contact among female sex workers in four sites in South Africa ( $\mathrm{N}=1636)$

\begin{tabular}{|c|c|c|c|c|c|}
\hline Variables & $\begin{array}{l}\text { Non-migrant } \\
\mathrm{n}=240 ; \mathrm{A}\end{array}$ & $\begin{array}{l}\text { Internal migrant } \\
\mathrm{n}=638 ; \mathrm{B}\end{array}$ & $\begin{array}{l}\text { Cross-border migrant; } \\
\mathrm{n}=758 ; \mathrm{C}\end{array}$ & $\begin{array}{l}P \text { value } \\
\text { A vs } C^{a}\end{array}$ & $\begin{array}{l}P \text { value } \\
\text { B vs C }\end{array}$ \\
\hline \multicolumn{6}{|l|}{ Economic dependence on sex work } \\
\hline Part-time sex work, n/N (\%) & $40 / 213(18.8 \%)$ & $150 / 606(24.8 \%)$ & $256 / 723(35.4 \%)$ & $<0.001$ & $<0.001$ \\
\hline $\begin{array}{l}\text { Median amount charged with last } \\
\text { client US\$ (IQR, range), } n\end{array}$ & $\begin{array}{c}13.3(13.3-24 \\
2.7-458.4), \mathrm{n}=233\end{array}$ & $\begin{array}{c}13.3(6.7-26.7 \\
1.5-466.7), \mathrm{n}=629\end{array}$ & $\begin{array}{c}20.0(10.7-40 \\
0.3-466.7), \mathrm{n}=754\end{array}$ & $0.01^{\mathrm{b}}$ & $<0.001^{\mathrm{b}}$ \\
\hline \multicolumn{6}{|l|}{ Unsafe working conditions ${ }^{c}$} \\
\hline Police interaction, last year, n/N (\%) & 86/197 (43.6 \%) & $217 / 537(40.4 \%)$ & $277 / 624(44.4 \%)$ & 0.86 & 0.17 \\
\hline Positive $^{\mathrm{d}}$ & 2/197 (1.0\%) & $2 / 537(0.4 \%)$ & $10 / 624(1.6 \%)$ & 0.55 & 0.04 \\
\hline Negative $^{e}$ & $59 / 197(30.0 \%)$ & $140 / 537(26.1 \%)$ & $192 / 624(30.7 \%)$ & 0.83 & 0.08 \\
\hline \multicolumn{6}{|l|}{$\begin{array}{l}\text { Nature of negative police interaction } \\
\text { in last year, } \mathrm{n} / \mathrm{N}(\%)^{\mathrm{f}}\end{array}$} \\
\hline Physical/sexual assault & 9/197 (4.6\%) & $24 / 537(4.5 \%)$ & $24 / 624(3.8 \%)$ & 0.65 & 0.60 \\
\hline Bribe & $5 / 197(2.5 \%)$ & $197 / 537(3.2 \%)$ & $33 / 624(5.2 \%)$ & 0.11 & 0.08 \\
\hline Immigration issues & $1 / 197(0.5 \%)$ & $1 / 537(0.2 \%)$ & $34 / 624(5.5 \%)$ & 0.003 & $<0.001$ \\
\hline Arrest & 40/197 (20.3\%) & $96 / 537(17.8 \%)$ & $109 / 624(17.5 \%)$ & 0.37 & 0.86 \\
\hline Other & 24/197 (12.2\%) & $39 / 537(7.3 \%)$ & $57 / 624(9.1 \%)$ & 0.21 & 0.25 \\
\hline \multicolumn{6}{|l|}{ Contact with health services } \\
\hline $\begin{array}{l}\text { Received facility or community-based } \\
\text { services in last month, } \mathrm{n} / \mathrm{N}(\%)\end{array}$ & $131 / 216(60.7 \%)$ & $352 / 595(59.2 \%)$ & $421 / 718(58.6 \%)$ & 0.60 & 0.85 \\
\hline $\begin{array}{l}\text { Condom-use with last client during } \\
\text { penetrative intercourse, } \mathrm{n} / \mathrm{N}(\%)\end{array}$ & $217 / 230(94.6 \%)$ & $558 / 626(89.1 \%)$ & $677 / 747(90.6 \%)$ & 0.08 & 0.36 \\
\hline
\end{tabular}

1US\$ $=7.5$ South African Rand

${ }^{a}$ Chi square test unless indicated

b Mann-Whitney $U$ test

c Post-coding free-text answers. Some participants gave insufficient information to classify interaction as positive or negative

${ }^{\mathrm{d}}$ Police assistance with laying a complaint or warning a participant about potential danger

e Police violence, arrest, harassment, theft, bribery or fines

${ }^{\mathrm{f}}$ Multiple-response question

following political and economic instability in Zimbabwe since the early $2000 \mathrm{~s}[21,63]$.

Our data challenges prevailing assumptions that position cross-migrants as the most disempowered sub-group within the sex industry [15, 34]. Compared to their internal or non-migrant colleagues, cross-border sex workers in this study had spent less time in the industry, had additional income-generating activities, worked mostly in the relatively safer indoor venues, and were older when they made their sex work debut. Cross-border migrants were also better educated than internal or non-migrants, similar to other studies in South Africa [26, 28]. Finally, this population had a higher client number than non-migrants, and charged more per client than internal or non-migrants.

Surprisingly few differences were observed in police interaction amongst the migrant groups. More cross-border migrants reported police requesting a bribe, possibly reflecting police's practice of extorting money or favours from cross-border migrants in relation to their status as non-nationals [49, 66]. Likely over time, police become familiar with sex workers in an area, explaining why interaction with police increases with duration in the industry.

Higher levels of contact with health services in Hillbrow could be attributed to the only sex work-specific clinic in South Africa operating there [42]. Overall, cross-border migrants had considerably less contact with health services than the other groups in multivariate analysis. Similarly, a study in Nairobi, Kenya found only $55 \%$ of migrant FSWs had ever accessed a health facility for an HIV-test in comparison to $78 \%$ of FSWs born in Kenya [24]. This may reflect an unwillingness of cross-border migrants to engage with public facilities due to fear of arrest in the case of an irregular legal status, or as a result of prior negative 
Table 3 Multivariate analysis of factors associated with part-time sex work, negative police interaction and health care utilization among female sex workers in South Africa

\begin{tabular}{|c|c|c|c|c|c|c|}
\hline \multirow[t]{2}{*}{ Variable } & \multicolumn{2}{|l|}{ Part-time sex work } & \multicolumn{2}{|c|}{ Negative police interaction } & \multicolumn{2}{|c|}{ Health care utilization } \\
\hline & $\begin{array}{l}\text { Univariate OR } \\
(95 \% \mathrm{CI})\end{array}$ & $\begin{array}{l}\text { Multivariate OR } \\
(95 \% \text { CI })\end{array}$ & $\begin{array}{l}\text { Univariate OR } \\
(95 \% \mathrm{CI})\end{array}$ & $\begin{array}{l}\text { Multivariate OR } \\
(95 \% \mathrm{CI})\end{array}$ & $\begin{array}{l}\text { Univariate OR } \\
(95 \% \mathrm{CI})\end{array}$ & $\begin{array}{l}\text { Multivariate OR } \\
(95 \% \mathrm{CI})\end{array}$ \\
\hline \multicolumn{7}{|l|}{ Age } \\
\hline $18-24$ & 1.0 & 1.0 & 1.0 & - & 1.0 & 1.0 \\
\hline $25-30$ & $1.14(0.83-1.56)$ & $1.38(0.94-2.04)$ & $1.20(0.85-1.69)$ & & $1.26(0.94-1.69)$ & $1.00(0.72-1.39)$ \\
\hline $30-35$ & $1.11(0.80-1.56)$ & $1.62(1.08-2.45)$ & $1.38(0.97-1.96)$ & & $0.89(0.66-1.20)$ & $0.82(0.58-1.15)$ \\
\hline $35+$ & $1.18(0.85-1.65)$ & $1.72(1.11-2.68)$ & $1.00(0.69-1.45)$ & & $0.87(0.64-1.18)$ & $0.77(0.54-1.11)$ \\
\hline \multicolumn{7}{|l|}{ Site } \\
\hline Cape Town & 1.0 & 1.0 & 1.0 & 1.0 & 1.0 & 1.0 \\
\hline Hillbrow, Johannesburg & $0.95(0.71-1.28)$ & $0.44(0.29-0.67)$ & $0.86(0.63-1.17)$ & $1.04(0.68-1.57)$ & $1.87(1.39-2.50)$ & $1.75(1.21-2.52)$ \\
\hline Rustenburg & $0.65(0.46-0.90)$ & $0.38(0.25-0.60)$ & $0.10(0.06-0.18)$ & $0.06(0.03-0.13)$ & $0.43(0.32-0.58)$ & $0.48(0.34-0.69)$ \\
\hline Sandton, Johannesburg & $1.18(0.83-1.67)$ & $0.54(0.34-0.86)$ & $2.12(1.47-3.05)$ & $1.82(1.15-2.88)$ & $0.81(0.58-1.14)$ & $0.82(0.56-1.21)$ \\
\hline \multicolumn{7}{|l|}{ Migration status } \\
\hline Non-migrant & 1.0 & 1.0 & 1.0 & 1.0 & 1.0 & 1.0 \\
\hline Internal migrant & $1.42(0.96-2.10)$ & $1.47(0.93-2.31)$ & $0.82(0.58-1.18)$ & $0.88(0.56-1.38)$ & $0.94(0.68-1.29)$ & $0.65(0.45-0.93)$ \\
\hline Cross-border migrant & $2.37(1.63-3.45)$ & $2.34(1.47-3.71)$ & $1.04(0.73-1.47)$ & $1.27(0.80-2.02)$ & $0.92(0.67-1.25)$ & $0.59(0.40-0.86)$ \\
\hline \multicolumn{7}{|l|}{ Education } \\
\hline Primary incomplete & 1.0 & 1.0 & 1.0 & 1.0 & 1.0 & 1.0 \\
\hline Completed primary & $1.30(0.94-1.79)$ & $1.34(0.89-2.01)$ & $1.15(0.83-1.60)$ & $0.95(0.61-1.46)$ & $1.40(1.06-1.85)$ & $0.85(0.62-1.18)$ \\
\hline Completed secondary school & $1.41(0.98-2.02)$ & $1.29(0.82-2.02)$ & $1.11(0.76-1.61)$ & $0.91(0.56-1.48)$ & $1.26(0.92-1.74)$ & $0.77(0.53-1.11)$ \\
\hline Some tertiary training & $2.39(1.46-3.91)$ & $2.00(1.12-3.59)$ & $0.50(0.27-0.92)$ & $0.46(0.22-0.94)$ & $1.45(0.90-2.33)$ & $1.03(0.61-1.74)$ \\
\hline \multicolumn{7}{|l|}{ Number of dependants } \\
\hline 0 & 1.0 & - & 1.0 & 1.0 & 1.0 & 1.0 \\
\hline $1-3$ & $1.13(0.73-1.76)$ & & $1.03(0.66-1.61)$ & $0.89(0.52-1.55)$ & $1.81(1.25-2.64)$ & $1.60(1.04-2.44)$ \\
\hline$\geq 4$ or more & $1.78(1.16-2.72)$ & & $1.20(0.78-1.86)$ & $0.78(0.45-1.35)$ & $2.79(1.93-4.03)$ & $2.09(1.35-3.25)$ \\
\hline \multicolumn{7}{|l|}{ Relationship status } \\
\hline Permanent partner & 1.0 & 1.0 & 1.0 & - & 1.0 & 1.0 \\
\hline Single & $3.41(2.71-4.30)$ & $2.77(2.13-3.60)$ & $1.24(0.97-1.58)$ & & $1.62(1.30-2.01)$ & $1.48(1.16-1.89)$ \\
\hline \multicolumn{7}{|l|}{ Main place solicits clients ${ }^{\mathrm{a}}$} \\
\hline Indoors & 1.0 & 1.0 & 1.0 & 1.0 & 1.0 & 1.0 \\
\hline Outdoors & $0.59(0.45-0.78)$ & $0.52(0.37-0.74)$ & $2.09(1.58-2.76)$ & $1.64(1.15-2.36)$ & $0.75(0.59-0.96)$ & $0.83(0.62-1.10)$ \\
\hline Combination of venues & $1.14(0.87-1.50)$ & $1.04(0.76-1.42)$ & $1.60(1.18-2.16)$ & $1.35(0.95-1.91)$ & $0.95(0.73-1.23)$ & $1.04(0.77-1.39)$ \\
\hline \multicolumn{7}{|l|}{ Duration in sex work } \\
\hline$<1$ years & 1.0 & 1.0 & 1.0 & 1.0 & 1.0 & - \\
\hline $1-5$ years & $0.84(0.60-1.16)$ & $0.71(0.49-1.04)$ & $1.93(1.27-2.94)$ & $2.15(1.36-3.39)$ & $0.99(0.73-1.36)$ & \\
\hline$>5$ years & $0.70(0.51-0.98)$ & $0.63(0.42-0.95)$ & $1.65(1.09-2.51)$ & $2.83(1.78-4.53)$ & $0.81(0.60-1.10)$ & \\
\hline
\end{tabular}

$O R$ odds ratio, $C I$ confidence interval

${ }^{a}$ Indoors includes working from brothels, bars or massage parlours; outdoors includes street-based sex workers

experiences [23, 47, 61], or as peer education services do not adequately reach this group. Migrant sex workers, compared to non-migrants, face greater discrimination and additional barriers to health, as well as social and legal services [53-55, 64]. Alternatively, it may point to the 'healthy migrant effect', where immigrants to a new community may on average be healthier on arrival than the host population [14, 30]. Regardless of the reason(s), strategies are required to ensure cross-border migrant sex workers can utilize health services, and in particular HIV and STI prevention and treatment services, when needed $[31,59,60]$.

The study has several limitations. It used a non-random sampling design and includes only self-reported data. 
Surveys were, however, conducted by trained peer interviewers-many migrants themselves-which may have minimised social-desirability bias. Multiple comparisons were made between study groups, increasing the changes of spurious findings. Even though questionnaires were available in five of the most widely spoken languages, some cross-border migrants may not be conversant in these, precluding their participation. Research sites were purposively selected and may not be generalizable to other sex work settings within the country. The three outcome variables selected describe only a limited number of risk factors associated with sex worker ill health and several others should have been assessed. In particular, workplace safety encompasses several factors other than negative police contact, such as exploitative managers or controllers, a violent neighbourhood and no condom supplies within sex work venues [3, 65]. Also, additional factors such as irregular immigration status, ethnic or racial discrimination and ghettoised work conditions are pertinent to migrant sex workers, as shown elsewhere [37]. Similarly, there may be instances where women elected to be fulltime sex workers because of its comparative higher earnings (not because of lack of alternatives) and they may make sufficient money to resist client overtures for unprotected sex.

In conclusion, our data illustrate the preponderance of migrants in sex work and the relative tenacity of crossborder migrants in South Africa. It illustrates the need for further sex work-specific health services, which specifically address health needs of migrant sex workers, especially around HIV/STI prevention. Such services should actively involve migrant sex workers in their design and planning, and as peer educators and outreach workers.

Acknowledgments We thank the Sex Worker Education and Advocacy Taskforce (SWEAT) and Sisonke Sex Worker Movement for guidance and logistical support, and the research assistants for data collection. Technical and logistical support of the African Centre for Migration \& Society and the Centre for Health Policy, Wits University and their students was key to conceptualising and developing the project, together with assistance of the Sex Worker Project, Wits Reproductive Health and HIV Institute in Hillbrow. Authors gratefully acknowledge the contribution to this work of the Victorian Operational Infrastructure Support Program. Special thanks for the contribution of Dudu Ndlovu, Dianne Massawe, Carolin Kueppers, Tom Considine, Fiona Scorgie, Elsa Oliveira, Agnieszka Flak, Marc Lewis, Ingrid Palmary, Richard Steen, Gerrit Maritz, Lucy Allais and Francois Venter. Thank you also Richard Steen for assistance with the conceptual framework and graphic representation thereof, and to Lenore Manderson, Eric Worby and Ziad El-Khatib for comments on earlier drafts of this manuscript Funding for this study was provided by UNFPA and Atlantic Philanthropies, while support of the Humanities Graduate Centre and the SPARC Fund at Wits University facilitated drafting of the manuscript.

Open Access This article is distributed under the terms of the Creative Commons Attribution License which permits any use, distribution, and reproduction in any medium, provided the original author(s) and the source are credited.

\section{References}

1. Adepoju A. Continuity and changing configurations of migration to and from the Republic of South Africa. Int Migr. 2003;41:3-28.

2. Agustin L. Sex at the margins: migration, labour markets and the rescue industry. New York \& London: Zed Books; 2007.

3. Akers N, Evans C. St James Infirmary Occupational Health \& Safety Handbook, San Francisco. 2010.

4. Akileswaran C, Lurie M. Overcoming socioeconomic struggle and encountering risk: lived experiences of South African female migrants. Annal Anthropol Pract. 2010;34:176-94.

5. Bähr J, Jürgens U. Johannesburg: life after apartheid. In: Schneider-Sliwa R, editor. Cities in transition: globalization. Political Change and Urban Development: Springer; 2006.

6. Baral S, Beyrer C, Muessig K, Poteat T, Wirtz A, Decker M, Sherman M, Kerrigan D. Burden of HIV among female sex workers in low-income and middle-income countries: a systematic review and meta-analysis. Lancet Infect Dis. 2012;. doi: 10.1016/S1473-3099(12)70066-X.

7. Biradavolu MR, Burris S, George A, Jena A, Blankenship KM. Can sex workers regulate police? Learning from an HIV prevention project for sex workers in southern India. Soc Sci Med. 2009;68:1541-7.

8. Blankenship KM, West BS, Kershaw TS, Biradavolu MR. Power, community mobilization, and condom use practices among female sex workers in Andhra Pradesh, India; 2008.

9. Bodin C, Richter M. Adult, consensual sex work in South Africa-the cautionary message of criminal law and sexual morality. S Af J Hum Rights. 2009;25:179-97.

10. Bujra JM. Women "Entrepreneurs" of Early Nairobi. Can J Af Stud. 1975;9:213-34.

11. Busza J. Having the rug pulled from under your feet: one project's experience of the US policy reversal on sex work. Health Policy Plan. 2006;21:329-32.

12. Campbell C. Selling sex in the time of AIDS: the psycho-social context of condom use by sex workers on a Southern African mine. Soc Sci Med. 2000;50:479-94.

13. Chersich MF, Luchters S, Ntaganira I, Gerbase A, Lo, Y-R, Scorgie F, Steen R. in press. Priority interventions to reduce HIV transmission in sex work settings in sub-Saharan Africa and delivery of these services. J Int AIDS Soc.

14. Deane KD, Parkhurst JO, Johnston D. Linking migration, mobility and HIV. Trop Med Int Health. 2010;15:1458-63.

15. Editorial. Prostitution and immigrants. The Herald Sun. 2011.

16. Evans C, Jana S, Lambert H. What makes a structural intervention? Reducing vulnerability to HIV in community settings, with particular reference to sex work. Glob Public Health. 2010;5:449-61.

17. Fick N. Sex workers experiences with the local law enforcement in South Africa. Research for Sex Work. 2005;8:4-8.

18. Fick N. Enforcing fear-police abuse of sex workers when making arrests. SA Crime Quart. 2006;16:27-33.

19. Fick N. Sex workers speak out-policing and the sex industry. SA Crime Quart. 2006;15:13-8.

20. Gould C, Fick N. Selling sex in Cape Town: sex work and human trafficking in a South African city. Institute for Security Studies: Pretoria/Tshwane; 2008.

21. Hammar A, Mcgregor J, Landau L. Introduction. Displacing Zimbabwe: crisis and construction in Southern Africa. J South Af Stud. 2010;36:263-83. 
22. Hawken MP, Melis RD, Ngombo DT, Mandaliya K, Ng'ang'a LW, Price J, Dallabetta G, Temmerman M. Part time female sex workers in a suburban community in Kenya: a vulnerable hidden population. Sex Transm Infect. 2002;78:271-3.

23. Human Rights Watch. No healing here-violence, discrimination and barriers to health for migrants in South Africa. New York: Hum Rights Watch; 2009.

24. International Organization for Migration. Healthy Migrants in Healthy Communities. In: Kenya mission with coordinating functions for the horn of Africa (ed.). Nairobi, Kenya; 2011.

25. Landau L. Transplants and transients: idioms of belonging and dislocation in inner-City Johannesburg. Af Stud Rev. 2006;49: 125-45.

26. Landau L, Gindrey V. Migration and populations trends in Gauteng Province, 1996-2055. In: Forced Migration studies programme; University of the witwatersrand; Johannesburg. (ed.) Migr Stud Work Paper Ser; 2008.

27. Landau LB. Discrimination and development? Immigration, urbanisation and sustainable livelihoods in Johannesburg. Develop South Af. 2007;24:61-76.

28. Landau LB, Wa Kabwe Segatti A. Human development impacts of migration: South Africa case study. In: Programme UnitedNationsDevelopment, editor. Human development reports. USA: United Nations Development Programme; 2009.

29. Luchters S, Chersich MF, Rinyiru A, Barasa M-S, King'ola N, Mandaliya K, Bosire W, Wambugu S, Mwarogo P, Temmerman $M$. Impact of five years of peer-mediated interventions on sexual behavior and sexually transmitted infections among female sex workers in Mombasa, Kenya. BMC Public Health, 8; 2008.

30. Malmusi D, Borrell C, Benach J. Migration-related health inequalities: showing the complex interactions between gender, social class and place of origin. Soc Sci Med. 2010;71:1610-9.

31. Mccarthy K, Chersich MF, Vearey J, Meyer-Rath G, Jaffer A, Simpwalo S, Venter WD. Good treatment outcomes among foreigners receiving antiretroviral therapy in Johannesburg, South Africa. Int J STD AIDS. 2009;20:858-62.

32. Nairne D. 'Please help me cleanse my womb' A hotel-based STD programme in a violent neighbourhood in Johannesburg. Res Sex Work. 1999;2:18-20.

33. Nairne D. 'We Want the Power' Findings from focus group discussion in Hillbrow, Johannesburg. Res for Sex work. 2000; 3:3-5.

34. O'connor CC, Berry G, Rohrsheim R, Donovan B. Sexual health and use of condoms among local and international sex workers in Sydney. Genitourin Med. 1996;72:47-51.

35. Pauw I, Brener L. 'You Are Just Whores: You Can't Be Raped': Barriers to safer sex practices among women street sex workers in Cape Town. Cult Health Sex, Nov-Dec 2003; 465-481.

36. Perberdy S. Mobile entrepreneurship: informal sector cross-border trade and street trade in South Africa. Develop South Af. 2000;17:201-9.

37. Platt L, Grenfell P, Fletcher A, Sorhaindo A, Jolley E, Rhodes T, Bonell C. Systematic review examining differences in HIV, sexually transmitted infections and health-related harms between migrant and non-migrant female sex workers. Sex Transm Infect; 2012.

38. Preston-whyte E, Tollman S, Landau L, Findley S. African Migration in the Twenty-First Century: Conclusion. In: Tienda M, Findley S, Tollman S, Preston-whyte E. (eds.) Africa on the move. African Migration and Urbanisation in Comparative Perspective. Johannesburg: Wits University Press; 2006.

39. Ramjee G, Karim SS, Sturm AW. Sexually transmitted infections among sex workers in KwaZulu-Natal, South Africa. Sex Transm Dis. 1998;25:346-9.

40. Rekart ML. Sex-work harm reduction. Lancet. 2005;366: 2123-34.
41. Research and Population UNIT. The people matter-The state of the population in the Eastern Cape. In: Makiwane MB, ChimereDan, DO (eds.) Department of Social Development. Pretoria: Human Sciences Research Council; 2010.

42. Richter M. Sex work, reform initiatives and HIV/AIDS in innercity Johannesburg. Af J AIDS Res. 2008;7:323-33.

43. Richter M, Luchters S, Ndlovu D, Temmerman M, Chersich MF. Female sex work and international sport events - no major changes in demand or supply of paid sex during the 2010 Soccer World Cup: a cross-sectional study. BMC Public Health. 2012;12:763.

44. Richter ML, Chersich MF, Scorgie F, Luchters S, Temmerman M, Steen R. Sex work and the 2010 FIFA World Cup: time for public health imperatives to prevail. Global Health. 2010;6:1.

45. SA Cities Network. State of Cities Report, 2006. Johannesburg; 2006.

46. Scorgie F, Chersich MF, Ntaganira I, Gerbase A, Lule F, Lo YR. Socio-demographic characteristics and behavioral risk factors of female sex workers in sub-saharan Africa: a systematic review. AIDS Behav. 2012;16:920-33.

47. Scorgie F, Nakato D, Ogutu AD, Netshivhambe M, Chakuvinga P, Nkomo P, Abdalla P, Sibanda S, Richter M. "I expect to be abused and I have fear": Sex workers' experiences of human rights violations and barriers to accessing healthcare in four African countries. In: African sex worker alliance (ed.) April ed. Johannesburg; 2011.

48. Shannon K, Montaner J. The politics and policies of HIV prevention in sex work. Lancet Infect Diseas. 2012;. doi:10.1016/ S1473-3099(12)70065-8.

49. South African Human Rights Commission. "Everything is not okay here. We are not treated like people." South African Human Rights Commission Report into the Arrest and Detention of Suspected Undocumented Migrants. Parktown: South African Human Rights Commission, 1999.

50. South African Law Reform Commission. Discussion Paper 0001/2009. Sexual Offences: Adult Prostitution South African Law Reform Commission; 2009.

51. Stadler J, Delany S. The 'healthy brothel': the context of clinical services for sex workers in Hillbrow, South Africa. Cult Health Sex. 2006;8:451-64.

52. Statistics South Africa. Census 2011. In: Statssa (ed.). Pretoria: Statistics South Africa; 2012.

53. Tampep. Sex Work, Migration, Health. In: European network for HIV/STI prevention and health promotion among migrant sex workers (ed.). Amsterdam: European Network for HIV/STI Prevention and Health Promotion among Migrant Sex Workers (TAMPEP) 2009.

54. UNAIDS. Sex Work and HIV/AIDS. In: Unaids (ed.) Techincal Update. Geneva 2002.

55. UNAIDS. UNADS Guidance Note: HIV and Sex Work 2007.

56. UNAIDS. Report on the global AIDS epidemic. Geneva: UNAIDS; 2011.

57. Unaids Advisory Group on HIV and Sex Work. The report of the UNAIDS Advisory Group on HIV and Sex Work. Geneva: UNAIDS; 2011.

58. Vanwiesenbeeck I. Another decade of social scientific work on sex work: a review of research 1990-2000. Ann Rev Sex Res. 2001;12:242-89.

59. Vearey J. Migration, access to ART, and survivalist livelihood strategies in Johannesburg. Af J AIDS Res. 2008;7:361-74.

60. Vearey J. Challenging urban health: towards an improved local government response to migration, informal settlements, and HIV in Johannesburg. South Africa: Glob Health Action; 2011. 4.

61. Vearey J. Learning from HIV: exploring migration and health in South Africa. Glob Public Health. 2012;7:58-70.

62. Vearey J, Oliveira E, Madzimure T, Ntini B. Working the City: experiences of migrant women in inner-city Johannesburg. South Af Gender Med Divers J. 2011;9:228-33. 
63. Vearey J, Palmary I, Thomas L, Nunez L, Drimie S. Urban health in Johannesburg: the importance of place in understanding intraurban inequalities in a context of migration and HIV. Health Place. 2010;16:694-702.

64. Vearey J, Richter M, Núñez L, Moyo K. South African HIV/ AIDS programming overlooks migration, urban livelihoods, and informal workplaces. Af J AIDS Res. 2011;10(Supplement): 381-91.

65. Vetten L, Dladla J. Women's fear and survival in inner-city Johannesburg. Agenda. 2000;45:70-5.

66. Vigneswaran D, Hornberger J. Beyond 'Good Cop'/BBad Cop': Understanding Informality and Police Corruption in South Africa.
In: FORCED Migration Studies Programme Wits University (ed.). Johannesburg 2008.

67. Vuylsteke B, DAS A, Dallabetta G, Laga M. Preventing HIV among sex workers. In: Mayer, K. \& Pizer, H. (eds.) HIV Prevention: A Comprehensive Approach. London: Academic Press; 2009.

68. WEBMISTRESS. Sex Worker Education \& Advocacy Taskforce (SWEAT) [Online]. 2010. Available: www.sweat.org.za.

69. Wojcicki JM, Malala J. Condom use, power and HIV/AIDS risk: sex-workers bargain for survival in Hillbrow/Joubert Park/Berea, Johannesburg. Social Sci Med. 2001;53:99-121. 